\title{
POTENSI PASIR LOKAL TANJUNG BINTANG PADA ALUMINIUM SAND CASTING TERHADAP POROSITAS PRODUK HASIL COR ALUMINIUM
}

\author{
Yusup Hendronursito ${ }^{* 1}$, Yogi Prayanda ${ }^{2}$ \\ ${ }^{1}$ Balai Penelitian Teknologi Mineral - LIPI, \\ Jl. Ir. Sutami Km 15 Tanjung Bintang Lampung Selatan \\ 2Jurusan Fisika FMIPA Universitas Lampung \\ *Email: yusu016@lipi.go.id
}

\begin{abstract}
Green sand is one of the most important components in the process of metal casting. The sand in Indonesia region is varied level of subtlety, size of sand, and shape of sand. Green sand used in the process of metal casting is possible can affect the quality of casting product. This aims to determine the potential of Tanjung Bintang sand as green sand and the quality of the product in terms of porosity defects. The research was conducted by varying sand river from Tanjung Bintang and sand from Maringgai. Composition made varying is $100 \%, 75 \%, 50 \%$, and 25\% Tanjung Bintang sand compared Maringgai sand with bentonit and water is 10\% and 5\% constantly. The Examine of the green sand by SNI 15-0312-1989 among other water content, clay content, Grain Finnest Number (GFN), Shape of grain. The result said aluminium casting product with $50 \%$ Tanjung Bintang sand has the lowest value of porosity, $5.08 \%$ and the higher value with $75 \%$ composition of Tanjung Bintang sand, $6.98 \%$.
\end{abstract}

Keywords: green sand, Tanjung Bintang sand, SNI 15-0312-1989, pororsity

\section{PENDAHULUAN}

Pasir merupakan bahan yang fundamental dalam proses pengecoran karena pasir adalah bahan yang paling banyak tersedia di alam. Pasir cetak yang umum digunakan adalah pasir gunung, pasir pantai, pasir sungai, dan pasir silika yang disediakan alam. Pasir cetak yang baik memiliki persyaratan seperti mempunyai sifat mampu bentuk, permeabilitas yang cocok, distribusi besar butir pasir yang baik, tahan terhadap temperatur logam yang tinggi, komposisi baik, pasir harus murah (Astrid dkk, 2007). Dalam prakteknya, sering dijumpai cacat pada pengecoran. Cacat-cacat pengecoran yang umum terjadi adalah kekasaran permukaan, cacat porositas didalam coran dan cacat-cacat yang disebabkan oleh runtuhnya cetakan. Sifat-sifat cetakan itu sendiri sangat tergantung pada distribusi besar butir pasir cetak, persentase zat pengikat dan persentase kadar air. Timbulnya cacat-cacat tersebut dipengaruhi oleh kemampuan alir gas (Permeabilitas) dan kekuatan cetakan yang kurang baik, hal itu bisa disebabkan karena campuran kadar air pada pasir cetak basah dengan bahan pengikat yang kurang ataupun kadarnya yang berlebihan. Bahan pengikat dalam hal ini adalah bentonit. Nurwidyanto dkk. (2006), telah melakukan penelitian hubungan ukuran butir terhadap permeabilitas dan porositas, diperoleh bahwa ukuran butir dengan porositas dan permeabilitas mempunyai hubungan linear yang kuat dan berkorelasi negatif yaitu semakin besar ukuran butirnya maka semakin kecil porositas dan permeabilitasnya. Sedangkan Sidiq dkk. (2014), melakukan penelitian terhadap kualitas hasil pengecoran pasir cetak basah dengan bentonit $3 \%$ dan $5 \%$ pada besi cor kelabu dimana diperoleh hasil dengan penambahan $5 \%$ spesimen memiliki harga kekerasan dan kuat tarik lebih besar dibandingkan dengan penambahan bentonit $3 \%$. Dody dkk. (2006), meneliti tentang jenis pasir silika, pasir tetes, dan pasir kali terhadap pengecoran besi cor kelabu. Diperoleh bahwa pasir silika memiliki nilai permeabilitas tertinggi dan pasir kali yang terendah sehingga disimpulkan bahwa pasir silika memiliki sedikit cacat pengecoran. Uswatun (2012), melakukan analisa variasi pasir cetak lokal jawa timur terhadap kekuatan cetakan pasir, fluiditas, dan kualitas hasil coran logam Al-Si dengan metode gravitasi casting.

Tanjung Bintang merupakan sebuah kecamatan di daerah Lampung Selatan. Memiliki bantaran sungai yang membentang dan sungai-sungai kecil lainnya. dari sungaisungai inilah didapatkan pasir sungai yang merupakan hasil gigisan batu-batuan yang keras dan tajam yang memiliki butiran antara $0.063 \mathrm{~mm}-5 \mathrm{~mm}$. Selama ini pasir Tanjung Bintang belum pernah digunakan sebagai pasir cetak. Karena karakter pasir antara daerah yang satu dengan daerah yang lain berbeda maka diperlukan uji karakterisasi pasir Tanjung Bintang. Penelitian ini diperlukan untuk mengetahui potensi pasir 
Tanjung Bintang sebagai pasir cetak terhadap hasil pengecoran, salah satunya terhadap pengecoran aluminium. Pasir cetak Tanjung Bintang dilakukan uji pasir cetak berdasarkan Standar Nasional Indonesia (SNI) 15-031212-1989 diantaranya Uji kadar Air, Uji Kadar Lempung, Uji Distribusi Persebaran Butir, dan Uji permeabilitas.

\section{METODE PENELITIAN}

Penelitian ini dilakukan dengan membuat cetakan pasir berbahan dasar pasir Tanjung Bintang dengan komposisi yang berbeda. Bahan baku yang akan digunakan berupa pasir Tanjung bbntang, pasir Maringgai, tanah lempung, air, dan almunium.

\section{Uji Kadar Air}

Uji kadar air dilakukan dengan mengambil $20 \mathrm{~g}$ contoh pasir yang telah disiapkan kemudian dikeringkan dalam ruang oven pada suhu 105 sampai $110{ }^{\circ} \mathrm{C}$. Pengeringan dilakukan sampai tercapai berat yang konstan. Kadar air diperoleh menurut rumus:

Kadar air $(\%)=$

berat pasir awal - berat pasir akhir berat pasir awal $x 100(1)$

dimana berat dinyatakan dalam gram ( $\mathrm{gr}$ )

\section{Uji Kadar Tanah Liat}

Pasir awal sebanyak 50 gram kemudian dimasukan kedalam gelas kimia dan tambahkan air $150 \mathrm{ml}$ dan $0,1 \%$ Larutan $\mathrm{KOH}$. Aduk Hingga Merata Selanjutnya menggunakan air mengalir untuk menghilangkan kadar lempung. Kemudian air ditiriskan dan selanjutnya dipanaskan dalam oven dengan suhu $110{ }^{\circ} \mathrm{C}$ untuk menghilangkan kadar air. Pasir kemudian ditimbang, perbedaan berat awal dan akhir dalam satuan prosentase sebagai kadar lempung bebas dalam campuran pasir. Kadar Lempung dihitung dengan rumus sebagai berikut :

Kadar lempung $(\%)=$ berat pasir awal-berat pasir akhir berat pasir awal

Bentonit atau tanah lempung merupakan bahan campuran pengikat pasir cetak, ikatan yang diciptakan ditambahkan kedalam komposisi cetakan pasir membentuk butiran penyusun struktur cetakan pasir yang
Penambahan bentonit dan air tetap sebesar $10 \%$ dan 5\%. Komposisi pasir Tanjung Bintang terhadap pasir Maringgai sebesar $100 \%$, $75 \%$, 50\%, dan 25\%. Pasir dibersihkan dari kotoran dan diayak dengan ayakan mesh 10 untuk memisahkan pasir dengan batu. Kemudian menimbang pasir Tanjung Bintang, pasir Maringgai, tanah lempung, dan air dengan komposisi yang telah ditentukan menggunakan neraca digital. Pembuatan pasir cetak dilakukan dengan mencampurkan pasir Tanjung Bintang, pasir Maringgai, bentonit, dan air dengan komposisi. Pengambilan sampel pasir cetak dilakukan pada masing-masing komposisi.

berbeda, sehingga permeabilitas yang diciptakanpun berbeda. Dari penelitian sebelumnya mengenai permeabilitas pada cetakan pasir yang telah dilakukan oleh Supriyadi dkk (2013) disebutkan bahwa nilai permeabilitas dipengaruhi oleh perbandingan jumlah bentonit yang ditambahkan kedalam cetakan pasir. Permeabilitas rendah dari cetakan pasir menjadi penyebab udara tidak dapat dengan baik disalurkan keluar keudara bebas, sehingga udara terperangkap didaam logam saat proses pembekuan. Udara yang terperangkap didalam logam saat proses pembekuan selesai menghasilkan ronggarongga didalam logam hasil pengeoran yang dikenal sebagai porositas.

\section{Uji Distribusi Persebaran Butir}

Penentuan distribusi besar butir dimaksudkan untuk menentukan nomor kehalusan butiran. Pengujian dilakukan dengan mempergunakan Shieve Shakers Model $R X-812$ dan susunan ayakan yang telah ditentukan. Peralatan ayakan yang digunakan dengan ukuran mesh 20, 40, 60, 80, dan 100. Pasir kering diambil dan ditimbang sebanyak $50 \mathrm{~g}$. Sampel campuran pasir dituangkan kedalam ayakan yang telah disusun berdasarkan ukuran mesh dan digoyangkan selama 15 menit dengan alat pengguncang. Setelah itu, pasir ditimbang pada tiap -tiap ukuran ayak menurut besar butir pasir. Selanjutnya menghitung prosentase dari beratnya tiap ayakan dengan rumus berikut :

$$
\begin{aligned}
& \text { Prosetase }(\%)= \\
& \frac{\text { berat pasir pada tiap ayakan }}{\text { jumlah berat dari spesimen }} \times 100
\end{aligned}
$$

Nomor kehalusan butir pasir dihitung dengan rumus dibawah ini, dengan mengalikan berat 
pasir pada tiap ayakan dengan angka pelipat $\mathrm{S}_{\mathrm{n}}$. Rumus kehalusan butir pasir adalah :

$$
F N=\frac{\sum\left(W_{n} S_{n}\right)}{\sum W_{n}}
$$

Dimana $F N$ adalah Nomor kehalusan Butir pasir, $W_{n}$ adalah Berat pasir diperoleh dari tiap ayakan (gram), $S_{n}$ adalah Angka pelipat.

\section{Pemeriksaan Bentuk Butiran}

Pemeriksaan bentuk butiran dilakukan dengan pengamatan dibawah mikroskop pada pembesaran 30 sampai 60 kali terhadap contoh pasir yang telah dicuci dan diayak. Dibedakan beberapa macam bentuk butiran: bulat, sebagian bersudut, bersudut, kristal. Bentuk butiran ditentukan dari bentuk butiran yang paling dominan dari contoh pasir bersangkutan. Bentuk butir dari berbagai jenis pasir dapat dilihat pada Gambar 1.

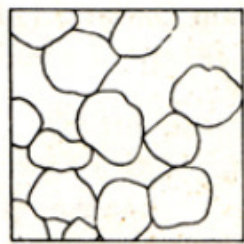

Butir pasir bulat.

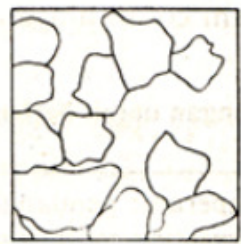

Butir pasir sebagian bersudut.

pengamatan fisik di permukaan (surface) dan permukaan dalam (subsurface) oleh karena itu perlu dilakukan grinding untuk mendapatkan permukaan yang halus. Sedangkan pengamatan cacat porositas secara kuantitatif akan dilakukan dengan metode perbandingan volume (Rizal dkk, 2012). Perhitungan prosentase porositas yang terjadi pada spesimen dengan rumus:

Porositas $=$
$\frac{V_{p}}{V_{t}} x 100 \%=\frac{V_{t}-V_{m}}{V_{t}}$

Dimana $V_{p}$ adalah volume porositas, $V_{t}$ adalah volume total, $m$ adalah masa, $\rho$ adalah densitas

\section{HASIL DAN PEMBAHASAN}

Telah diakukan penelitian tentang karakterstik campuran pasir cetak dan porositas hasil cor almunium. Dalam penelitian ini, ada beberapa karakteristik

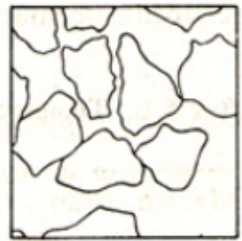

Butir pasir bersudut.

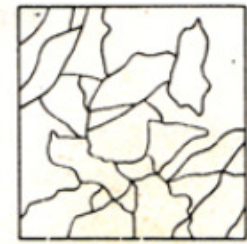

Butir pasir kristal.

\section{Gambar 1. Bentuk butir pasir}

\section{Porositas}

Peleburan aluminium dilakukan di tungku lebur dengan menggunakan kowi. Aluminium dicairkan dengan tungku pembakaran hingga mencair, dimana temperatur peleburan berkisar antara 500 $550{ }^{\circ} \mathrm{C}$. Setelah aluminium dituang kedalam cetakan, ditunggu sekitar 1 hari kemudian cetakan dibongkar untuk mendapatkan spesimen hasil coran. Inspeksi cacat porositas dilakukan secara kualitatif dan kuantitatif. Pengamatan cacat secara kualitatif dilakukan dengan cara melakukan campuran pasir cetak yang telah diuji yaitu : uji kadar air, uji kadar lempung, uji permeabilitas dan uji persebaran butir pasir. Adapun untuk pengujian porositas terhadap hasil cor almunium merupakan bahan yang menjadi hasil pengecoran dengan teknik menggunakan media cetakan pasir dengan komposisi campuran pasir cetak yang berbeda-beda

\section{Kadar Air}

Hasil uji kadar air dapat dilihat pada Tabel 1.

Tabel 1. Hasil ujir kadar air

\begin{tabular}{ccccc}
\hline Sampel & $\begin{array}{c}\text { Berat Awal } \\
(\mathrm{gr})\end{array}$ & $\begin{array}{c}\text { Berat Akhir } \\
(\mathrm{gr})\end{array}$ & $\begin{array}{c}\text { Kadar Air } \\
(\%)\end{array}$ & $\begin{array}{c}\text { Rata-rata } \\
(\%)\end{array}$ \\
\hline Pasir A & 60 & 57,78 & 3,74 & 3,76 \\
& 60 & 57,71 & 3,81 & \\
Pasir B & 60 & 58,53 & 2,45 & 2,57 \\
& 60 & 58,38 & 2,70 & \\
\hline
\end{tabular}




\begin{tabular}{lllll}
\hline Pasir C & 60 & 57,57 & 4,05 & 4,04 \\
& 60 & 57,58 & 4,03 & \\
Pasir D & 60 & 57,64 & 3,93 & 3,93 \\
& 60 & 57,64 & 3,93 & \\
\hline
\end{tabular}

Didapatkan nilai kandungan kadar air dengan rata- rata berturut sebesar $3,76 \%$, $2,57 \% \%, 4,04 \%$, dan 3,93 \% dari pasir A,B,C, dan D.Dari grafik diatas didapatkan bahwa uji kadar air pada keempat sample campuran pasir cetak diperoleh nilai persentase kadar air yang memenuhi syarat untuk pasir cetak. Dimana syarat kadar air untuk pasir cetak adalah $2 \%-12 \%$.

\section{Kadar Lempung}

Keempat sampel yang telah dilakukan pengujian sebelumnya berasal dari campuran $10 \%$ tanah lempung atau bentonit dari berat bahan keseluruhan. Kadar lempung yang didapat pada penelitian ini lebih dari $10 \%$. Dimana nilai $10 \%$ merupakan syarat pasir cetak.

\section{Uji Permeabilitas}

Hasil uji permeabilitas dapat dilihat pada Tabel 3.

\section{Distribusi Persebaran Butir}

Pengujian distribusi persebaran pasir di lakukan di laboratorium uji kimia LIPI tanjung Bintang. Pengujian menghasilkan dua jenis data hasil pengujian yaitu data presentase berat tiap ayakan dan data nomor kehalusan butir (GFN). Dan dari pengujian persebaran butir, didapatkan hasil yang disajikan pada Table 5.

Tabel 2. Hasil uji kadar lempung

\begin{tabular}{cc}
\hline Sampel & $\begin{array}{c}\text { Rata }- \text { Rata kadar } \\
\text { Lempung }(\%)\end{array}$ \\
\hline Pasir A & 12,22 \\
Pasir B & 10,59 \\
Pasir C & 11,22 \\
Pasir D & 10,90 \\
\hline
\end{tabular}

Tabel 3. Hasil uji permeabilitas

\begin{tabular}{cccc}
\hline Cetakan Pasir & $\begin{array}{c}\text { Pasir Tanjung } \\
\text { Bintang }\end{array}$ & $\begin{array}{c}\text { Pasir } \\
\text { maringgai }\end{array}$ & $\begin{array}{c}\text { Permeabilitas } \\
\text { (cm3/mnt) }\end{array}$ \\
\hline Pasir A & $100 \%$ & $0 \%$ & 266.67 \\
Pasir B & $75 \%$ & $25 \%$ & 153 \\
Pasir C & $50 \%$ & $50 \%$ & 195 \\
Pasir D & $25 \%$ & $75 \%$ & 151 \\
\hline
\end{tabular}

Tabel 4. Jumlah pasir pada masing masing pengujian campuran pasir cetak

\begin{tabular}{lllllllll}
\hline Ayakan & Pasir A & \multicolumn{3}{c}{ Pasir B } & \multicolumn{3}{c}{ Pasir C } & \multicolumn{2}{l}{ Pasir D } \\
\hline & $\mathrm{I}$ & II & I & II & I & II & I & II \\
Jumlah & 44,76 & 45,84 & 46,11 & 46,27 & 45,72 & 45,93 & 47,01 & 47,05 \\
seharusnya & 44,88 & 45,90 & 46,12 & 46,29 & 45,84 & 45,94 & 47,02 & 47.08 \\
hilang & 0,12 & 0,06 & 0,01 & 0,02 & 0,12 & 0,01 & 0,01 & 0,03 \\
\hline
\end{tabular}

Tabel 5. Nilai persebaran butir

\begin{tabular}{ccccccccc}
\hline Nilai & \multicolumn{2}{c}{ Pasir A } & \multicolumn{2}{c}{ Pasir B } & \multicolumn{2}{c}{ Pasir C } & \multicolumn{2}{c}{ Pasir D } \\
\cline { 2 - 8 } GFN & I & II & I & II & I & II & I & II \\
Rata-rata & 45,24 & 44,61 & 48,43 & 46,32 & 52,15 & 46,78 & 52,53 & 53,89 \\
\hline
\end{tabular}


Dari perhitungan didapatkan nilai ratarata kehalusan butir (GFN) sebesar $(44,92)$, $(47,37)$, $(49,46)$, dan $(53,21)$ pada masingmasing campuran pasir cetak. Dari Tabel 3. diatas, didapatkan hasil bahwa GFN yang didapatkan pada penelitin ini menunjukkan bahwa campuran pasir cetak yang dibuat telah memenuhi syarat pasir cetak yaitu batas bawah sebesar 40 .

\section{Bentuk Butir Pasir}

Bentuk butir pasir Tanjung Bintang dapat dilihat pada Gambar 2. Dari pengujian bentuk pasir dapat dilihat bahwa sebagian besar butir pasir Tanjung Bintang berbentuk sebagian bersudut.

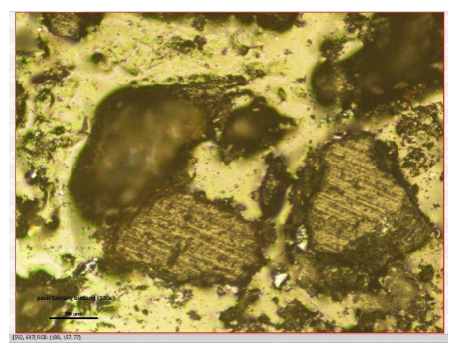

Gambar 2. Bentuk butir pasir tanjung bintang perbesaran 100x

\section{Uji Porositas}

Nilai pororsitas pada masing-masing spesimen dapat dilihat pada Tabel 6 .

Tabel 6. Hail uji porositas pada masing-masing specimen hasil cor

\begin{tabular}{cccc}
\hline Sampel & $\mathrm{V}(\mathrm{cm} 3)$ & $\begin{array}{c}\text { Massa } \\
(\mathrm{gr})\end{array}$ & $\begin{array}{c}\text { Angka Porositas } \\
(\%)\end{array}$ \\
\hline Spesimen A & 68,63 & 174,45 & 5,84 \\
Spesimen B & 67,69 & 170,00 & 6,98 \\
Spesimen C & 67,38 & 172,68 & 5,08 \\
Spesimen D & 66,92 & 169,61 & 6,11 \\
\hline
\end{tabular}

Dari penelitian yang dilakukan, didapatkan hasil nilai rata- rata porositas yang berturut turut adalah $5,84 \%, 6,98 \%, 5,08 \%$, dan 6,11 dari masing- masing campuran pasir cetak. Dapat dilihat bahwa angka porositas terbesar terletak pada spesimen B yang merupakan hasil pengecoran dari almuniun yang menggunakan media pasir cetak dengan campuran pasir cetak $75 \%$ pasir Tanjung Bintang. Nilai porositas dipengaruhi oleh terjebaknya gelembung-gelembung gas pada logam cair ketika dituangkan ke dalam cetakan (Budinski, 1996). Penyebabnya antara lain kontrol yang kurang sempurna terhadap absorbsi gas dengan logam selama peleburan dan penuangan.

\section{KESIMPULAN}

Berdasarkan pengujian kadar air dan GFN pasir Tanjung Bintang memenuhi syarat sebagai pasir cetak namun perlu diteliti ulang untuk penambahan kadar tanah liat diatas $10 \%$ mengingat dari hasil bentuk butir pasir dari pasir cetak berbentuk butir pasir kristal dimana bentuk ini memerlukan jumlah pengikat yang lebih banyak untuk memperoleh kekuatan dan permeabilitas tertentu. Dari hasil inspeksi cacat pengecoran porositas semua sampel mengalami cacat porositas. Nilai permeabilitas hasil pengecoran menggunakan pasir Tanjung Bintang berbanding terbalik dengan nilai porositasnya. Nilai permeabilitas yang tinggi pada pasir cetak menghasilkan porositas yang kecil, untuk itu perlu dilakukan penelitian lanjutan untuk meningkatkan nilai permeabilitas dari pasir cetak tersebut.

\section{UCAPAN TERIMAKASIH}

Penulis mengucapkan terimakasih kepada BP. Teknologi Mineral - LIPI Lampung yang telah memberikan dukungan serta fasilitas di dalam penelitian ini.

\section{DAFTAR PUSTAKA}

Astrid P.N., Bona M., Irma S., Nadia F.R., Prila S.L.R., Ira W., 2007, , Pengujian pasir cetak, Laporan Praktikum Proses Manufaktur Modul V, Teknik Mesin, Institut Teknologi Bandung.

Budinski G.K., 1996, Engineering Material Properties and Selection, Prentice Hall, Inc, Englewood Cliffs, New Jersey.

Dody A., Wahyu P.R., Saiful A., 2006, Hubungan variasi jenis pasir cetak terhadap sifat mekanik besi cor kelabu, Jurnal Mekanika, Vol. 4, No. 2.

Nurwidyanto M.I., Meida Y., Sugeng W., 2006, Pengaruh ukuran butir terhadap porositas dan permeabilitas pada batupasir, Berkala Fisika, Vol. 9, No.4, 191-195.

Rizal M.P., Soeharto, 2012, Studi eksperimen pengaruh jenis saluran pada aluminium 
sand casting terhadap porositas produk toroidal piston, Jurnal Teknik ITS Vol. 1, No. $1,126-130$

Sidiq B., Budi H., Yuyun E., 2014, Perbandingan kualitas hasil pengecoran pasir cetak basah dengan campuran bentonit $3 \%$ dan $5 \%$ pada besi cor kelabu, Jurnal Nosel, Vol. 2, No. 3

Standar Nasional Indonesia (SNI) 15-031212-1989, 1989, Pasir cetak, Cara uji. Badan Standarisasi Nasional. ICS 91.100 .15
Supriadi H., Sewandono D., 2013, Pengaruh variasi abu sekam dan bentonit pada cetakan pasir terhadap kekerasan dan struktur mikro hasil coran alumunium aa 1100. Jurnal IImiah Teknik Mesin, Vol.1 No.3

Uswatun S., 2012, Analisis variasi pasir cetak lokal jawa timur terhadap kekuatan cetakan pasir, fluiditas, dan kualitas hasil coran logam al-si dengan metode gravitasi casting, Skripsi, Fakultas Teknik Um. 